\title{
Susan Zimmermann
}

\subsection{Eastern Europe}

This chapter gives a glimpse into past and present historiographies of labour in East Central Europe, South-eastern Europe, and Eastern Europe including the post-Soviet territories. The focus is on writings on the history of labour in Eastern Europe, or the region so defined, between the early modern period and 1989-1991. I have considered here only what has been published since the 1960s, and the emphasis is on labour from the nineteenth century onwards. My aim has been to explore how that historiography has contributed to the development of an inclusive type of global labour history - or contains the potential to do so. I therefore present here a selective and somewhat generous reading ${ }^{1}$ of the scholarship discussed, foregrounding two interconnected aspects. I shall explore to what extent and in what ways the literature has been attentive to some of those groups of workers, and to some of those forms of work and labour, and labour conditions and relations that have often been rendered marginal in classical labour history. In addition, I shall discuss how the literature has invoked trans-local, transnational, comparative, or universal horizons, and in particular how it has characterized and explained local or regional characteristics of the history of labour with reference to such broader horizons.

Foregrounding those two themes might suggest an undue lack of emphasis on the inherent value - indeed the indispensability - to any project intended to advance global labour history of regional historiography on its own account. However, this chapter will demonstrate that the chosen focus, at least in the case of Eastern Europe, allows a re-evaluation of important traditions and trajectories of such regional historiography from a global perspective. The related argument evolves from my interest in a third thing that has guided me through this essay - the question of whether and how the new global labour history has been affected by or partaken in increasingly globalized and often asymmetric circuits of knowledge. I wonder what the effect has been of the corresponding adulation or even fetishization of some scholarship on the one hand, and the devaluation of much Eastern European scholarship and its producers on the other. In this essay I shall seek to counteract such harmful possibilities.

After an introductory section on the relevant waves of labour historiography, I shall discuss how the literature has addressed „special“ groups of workers and „special“ forms of labour. I have paid attention to concepts and horizons, with the particular aim of including comparative studies, and I read the literature produced during both waves as situated knowledge production.

1 A presentation by Alexandra Ghit (European Social Science History Conference, Valencia 2016) first drew my attention to this concept. 


\section{Waves}

Eastern European historiography has been important to the process by which labour history developed from the 1960s to the end of state socialism in 1989-1991 into a more respectable and internationally accepted branch of research. This I shall refer to as „Wave One“. Within state-socialist Europe, research into the history of the working class and the labour movement was at the core of the state-promoted agenda for historical research. For example, in Hungary, ${ }^{2}$ among other countries in the region, key institutions regarded both the large-scale opening of the archives after 1945 and explicit promotion of research into the modern capitalist epoch as important means of generating support for systemic change to socialism. After Stalin's death there were a great many institutions and publications dealing with many aspects of the history of labour. The Revue Roumaine d'histoire, established in 1962 and before long published several times a year, had before the end of the decade addressed a diverse range of topics. Articles appeared on the 1907 peasant revolt in an international context, the „heroic struggles“ of railway and petroleum workers against the fascistization of the country in 1933, Lenin's address to the workers and peoples of Austria-Hungary in 1918, the steps towards the unification of Romania as mirrored in socialist thinking, and the contribution of the labour and socialist movement to unification. The journal examined the fight of Romanian workers for the liberation of Ernst Thälmann, looked at relations between Romanian and French workers and socialists between 1880 and 1900, and dissected socialist international relations in South-eastern Europe at the end of the nineteenth and the beginning of the twentieth centuries. Karl Marx featured, too, with the Romanians' struggle for social emancipation and national liberation, and there was a recounting of the diffusion of knowledge about Marx's Capital in Romania in the late nineteenth century. For earlier periods the journal gave space to pieces on the guilds in Moldova and Walachia in the tenth to the seventeenth century. Later, in 1979, came a study of international and Romanian activities aimed at the rationalization of labour and production in the interwar period, and in 1981 a cluster of articles on the social and legal history of peasants. In 1986 a study was included about Italian workers in Romania before World War I. ${ }^{3}$

While historiographical accounts of different countries agree that labour history blossomed in terms of published output and broadened and diversified thematically, they disagree widely as to the extent of scholarly, thematic, and conceptual openness

2 Péter Gunst, A magyar történetírás története (Debrecen, 1995), p. 191.

3 The list is exhaustive in terms of the contributions on labour history included in the journal. The language of the journal was predominantly French. 
and achievement. ${ }^{4}$ More historiographical research needs to be done before substantial comparisons across the region and globally are possible.

The early and strong presence in Eastern Europe of labour history at the core of the historian's profession and of national research infrastructures had visible repercussions internationally, as did its centrally designed and vividly discussed research agenda. In the context of the Cold War and against the background of a growing international presence from the later 1950s onwards of „undogmatic“ Marxist and socialist historians from Western countries and the de-petrification of Eastern European historical research, the Eastern European challenge contributed to making social and labour history more attractive in the West from the 1960s onwards. By 1989 the activities developed by the International Conference of Labour and Social History (ITH) had been documented in seventeen volumes, bringing together labour history writing from both sides of the Iron Curtain (including a number of contributions on the history of labour in the Global South) since 1964. The contributors showed a strong focus on the history of the labour movement in all its variations, including its international dimensions and its relationships to colonialism, imperialism, and war. They also tackled themes such as the involvement of women, the historical geography of Marxism, the question of workers' consciousness, the status of the working class in various contexts, labour migration, and the „problems of the emergence and political formation of the working class“. The volumes also give extensive bibliographical information as well as information about research institutions, sources, and documentation, and they repeatedly document the discussion of research methods. ${ }^{5}$

Scholarship produced and published in state-socialist Europe between the 1960s and the 1980s followed and co-shaped the dominant trends of the period, such as writing labour history as the social history of the constitution, and the position of the working class. Flagship journals of the historical profession likewise addressed that large theme repeatedly as well as dealing with the more classical history of the labour movement. In 1978 Acta Poloniae Historica, published in Western languages, dedicated a whole volume to labour history. It included contributions on historiography, differentiation and integration, „cultural heritage“ and the political attitudes of the working class. ${ }^{6}$ The highly variable character and uneven development of the working class was made clear in Jürgen Kuczynski's forty-volume Die Geschichte der Lage der Arbeiter unter dem Kapitalismus [History of the Position of the Workers under Capitalism] published between 1960 and 1972. That monumental work included a volume on women workers in Germany since 1700 and another that gave Eine Weltübersicht über die Geschichte der Lage der Arbeiter [Global Overview on the History of the Po-

\footnotetext{
4 Andrei Sokolov, „The Drama of the Russian Working Class and New Perspectives for Labour History in Russia“, in: Jan Lucassen (ed.), Global Labour History: A State of the Art (Bern, 2006), pp. 399-411, gives a detailed account of the development of labour history in the Soviet Union. 5 https://search.socialhistory.org/Record/COLL00300, last accessed 20 March 2017. 6 Acta Poloniae Historica, 38 (1978).
} 
sition of the Workers] (1963 and 1967 respectively). ${ }^{7}$ Miklós Lackó's carefully researched and methodologically reflective Ipari munkásságunk összetételének alakulása: 1867-1949 [The Evolution of the Composition of our Working Class 1867-1949] (1961) similarly focused on the variable character and uneven development of the history of labour, exploring the social origin, composition, and stratification of the Hungarian industrial working class and describing the various types of workers belonging to this class. Besides statistical and other primary material, the study used the author's own sociographic encounters with many workers. For instance, it paid attention to how the gender and national composition of the workforce was related to the division between skilled and unskilled workers, migratory processes, geographic differentiation, and the development of the labour movement. Lackó was careful to refer closely to his rich data to underline again and again that the industrial labour force had been of „mixed“ composition, and highlight the „transitional forms“ of wage labour. He pointed out, too, that „double-residence“ or „perpetual fluctuation“ of large parts of the Hungarian working class between agriculture and industry persisted well into the interwar period. Lackó gave some explanatory background in rather schematic sections on economic development and the unequal „international division of labour“ in Europe. ${ }^{8}$ Meanwhile, in the 1960s the Soviet Union saw the multi-volume publication of Istoriya Komministicheskoj Partii Sovietskogo Sojuza [The History of the Communist Party of the Soviet Union] and then, in 1981, the launch of the nine-volume Istoriia rabochego klassa SSSR and Istoriia sovetskogo rabochego klassa [History of the Working Class of the USSR], which offered valuable data and accumulated knowledge within the confines of a restrictive ideology. ${ }^{9}$

Among Western academics the Wave One period similarly brought the heyday of the by-now classic variants of the social history of the working class, some of which was oriented more towards structure while other versions also explored workers' agency. That context was conducive to scholarship on Eastern European labour, too, and the Anglo Saxon tradition of Russian and Soviet studies in particular generated important work on the history of labour in Russia and the Soviet Union. ${ }^{10}$ For presocialist Russia the work of Reginald E. Zelnik, among others, was groundbreaking. ${ }^{11}$

7 Jürgen Kuczynski, Studien zur Geschichte der Lage der Arbeiterin in Deutschland von 1700 bis zur Gegenwart, Die Geschichte der Lage der Arbeiter unter dem Kapitalismus, 40 vols, vol. 18 (Berlin, 1963), idem, Eine Weltübersicht über die Geschichte der Lage der Arbeiter, Die Geschichte der Lage der Arbeiter unter dem Kapitalismus, 40 vols, vol. 37 (Berlin, 1967).

8 Miklós Lackó, Ipari munkásságunk összetételének alakulása: 1867-1949 (Budapest, 1961), especially pp. $11 \mathrm{ff} ., 30-33,138 \mathrm{f}$.

9 Sokolov, „The Drama of the Russian Working Class“, p. 407.

10 The introduction in Donald Filtzer et al. (eds), A Dream Deferred. New Studies in Russian and Soviet Labour History (Bern, 2008), and Lewis Siegelbaum, „Workers and Industrialization“, in: Ronald Grigor Suny (ed.), The Twentieth Century, vol. 3, The Cambridge History of Russia (Cambridge, 2006), pp. 440 467, provide good overviews of research and scholarship in the pre- and post-1991 periods.

11 Reginald E. Zelnik, Labor and Society in Tsarist Russia. The Factory Workers of St. Petersburg 18551870 (Stanford, CA, 1971). 
Regarding the Soviet period, there were important studies on the entanglement of and tensions between economic policies, including the wider contexts and pressures generating them, on the one hand, and on the other hand labour relations broadly conceived. ${ }^{12}$ The scholarship also discussed issues such as the living conditions of the working population.

If, in the West, postmodern and cultural turns caused a crisis in the conception of labour history as the social history of the working class, in Eastern Europe 1989-1991 marked a rupture both much harsher and more tangible. In most of East Central and South-eastern Europe the decline was steeper than in Western Europe in terms of both the devaluation of all earlier scholarship on the history of labour and the virtual disappearance of any related themes or subjects from the research agenda until well into the 2000s. Within and in relation to Russia and certain of the former Soviet territories, and perhaps Poland and the Czech Republic, things never reached quite such a pass as they did in the rest of East Central and in South-eastern Europe during the 1990s. In Russia the degradation of the inherited research infrastructure and institutions was less pronounced, and that might be because the denigration of the statesocialist past or some aspects of it was more contested there than elsewhere. In addition, the Anglo Saxon tradition of Russian and Soviet studies in the 1990s profited greatly from the opening up of many archives, and especially in that period this tradition functioned as the prime platform preventing the complete disappearance of Russian labour history. In that context, the International Institute of Social History in Amsterdam also played a visible role. As a result, the output of internationally visible scholarship on the history of labour in Russia and the Soviet Union continued throughout the 1990s. ${ }^{13}$

Since the 2000s, accompanied by both a visible brain drain from East to West and pronounced if asymmetric internationalization of research and scholarly infrastructures within and beyond Europe, we have seen the beginning of a new wave of interest in labour history all over Eastern Europe; this I shall refer to as „Wave Two“. With regard to many countries in the region, the resurgence so far has been characterized by a strong focus on labour under state socialism and state socialism as a quintessentially

12 Donald Filtzer, Soviet Workers and Stalinist Industrialization. The Formation of Modern Soviet Production Relations, 1928-1941 (London etc., 1986).

13 For example, Lewis H. Siegelbaum and Ronald Grigor Suny, Making Workers Soviet: Power, Class, and Identity (Cambridge, 1994). Sokolov, „The Drama of the Russian Working Class“, especially pp.413417, gives concrete information on the activities of Western scholars and institutions in this period and their role for developments in Russia. In his 2006 survey article on pre- and post-1989-1991 AngloSaxon scholarship on labour in the Soviet Union, Lewis Siegelbaum basically describes the publications appearing in the 1990s as a late outlet of the earlier „romance“ of this scholarship with the Soviet worker. Siegelbaum claims that from the late 1980s onwards class as a category of analysis was „dislodge[d] ... from its privileged position“ in Anglo-Saxon historiography on labour in the Soviet Union, and that scholarship largely turned away from its earlier interest in workers and labour. Lewis $\mathrm{H}$. Siegelbaum, „The Late Romance of the Soviet Worker in Western Historiography“, International Review of Social History, 51, 3 (2006), pp. 463-481, esp. 476-478. 
labour-oriented social formation. ${ }^{14}$ For the time being, there is more research going on into the beginnings and the ending of state socialism, including the transition, than there is on the period between the 1960s and the mid-1980s. ${ }^{15}$ Similarly, new studies on labour in the decades before the Eastern expansion of National Socialism are still rare for East Central and South-eastern Europe. ${ }^{16}$ A particularly neglected large theme within Wave Two is the history of workers' organizations and labour movements in Eastern Europe. However, recently a number of cross-country and transnational studies have begun to carve out new terrain with regard to workers' organizations and labour movements too. ${ }^{17}$ In general Eastern Europe's new labour history has not yet become very visible within nor integrated into the new global labour history.

14 Important cross-country collections of articles were published in Bohemia: A Journal of History and Civilisation in East Central Europe, 42, 2 (2001), „Sozialgeschichtliche Kommunismusforschung“; Peter Hübner, Christoph Klessmann, and Klaus Tenfelde, Arbeiter im Staatssozialismus: Ideologischer Anspruch und soziale Wirklichkeit (Cologne, 2005); International Labor and Working-Class History, 68 (2005), „Labor in Postwar Central and Eastern Europe“. Mitteilungsblatt des Instituts für Soziale Bewegungen, 37 (2007), „Sowjetische Bergleute und Industriearbeiter - Neue Forschungen“, assembles studies on Russian and other post-Soviet territories. Important reviews and bibliographical essays in English and not contained in any of these collections include: Peter Heumos, „Workers under Communist Rule: Research in the Former Socialist Countries of Eastern-Central and South-Eastern Europe and in the Federal Republic of Germany“" International Review of Social History, 55, 1 (2010), pp. 83-115; Tuong Vu, „Workers under Communism: Romance and Reality“, in: Stephen A. Smith (ed.), The Oxford Handbook of the History of Communism (Oxford, 2013), pp. 471-487.

15 Recent examples dealing with the period from the 1960s onwards include Eszter Bartha, Alienating Labour: Workers on the Road from Socialism to Capitalism in East Germany and Hungary (New York, 2013), and Eeva Kesküla, „Fiddling, Drinking and Stealing: Moral Code in the Soviet Estonian Mining Industry“, European Review of History/ Revue européenne d'histoire, 20, 2 (2013), pp. 237-253. The collections cited above also include a few examples of research with a focus on the „middle“ period, notably by Lenka Kalinová and Eszter Zsófia Tóth.

16 Examples include Rudolf Kučera, Život na př́děl. Válečná každodennost a politiky dělnické třídy $v$ českých zemích 1914-1918 (Prague, 2013). On pre-Soviet Russia (and the Soviet Union) see Filtzer et al., A Dream Deferred.

17 In relation to the Yugoslav territories and the border region with Italy, Sabine Rutar, „Towards a Southeast European History of Labour: Examples from Yugoslavia“, in: idem (ed.), Beyond the Balkans: Towards an Inclusive History of Southeastern Europe (Münster, 2013), pp. 337-342, 348 - 353, discusses in detail some of this work, including her own. Craig Phelan (ed.), Trade Unionism since 1945: Towards a Global History, vol. 1 (Oxford, 2009); Stefan Müller, „West German Trade Unions and the Policy of Détente (1969 - 1989)“, Moving the Social. Journal of Social History and the History of Social Movements, No. 52 (2014), pp. 109-137. 


\section{Agricultural labour}

The period before 1989 gave rise to the detailed study of many forms of agrarian labour, ${ }^{18}$ including the labour force that seemed to have been lingering somewhere between an agricultural way of life and various forms of proletarianization. In the most basic sense, that was simply because in the nineteenth and the first half of the twentieth centuries agrarian labour in the broad sense of the term had been the dominant form of labour in most regions of Eastern Europe. In Russia in 1900 eighty per cent of the population were peasants, and they never acknowledged any claim to land by anyone who did not work it. ${ }^{19}$ In addition, in many places agrarian labour had been associated with exploitation and misery, and repeatedly with labour struggle and radicalism. As state socialism and thus Wave One came to its end, historiography had created differentiated knowledge about the varieties of labour relations involving agrarian labour, the related history of agrarian unrest and rebellion, and the comparative history of agrarian development. Some of this historiography referred to the history of agrarian labour as shaped by both pan-European and global economic developments and divisions of labour, and local politics, when discussing developments in Eastern Europe. ${ }^{20}$

Other factors more specific to Eastern Europe contributed to the strength of the historiography of agricultural labour. In some cases peasant studies, conceived of as a branch of historical studies separate from the more mainstream history of the labour movement, flourished because less mainstream historians, especially those inclined to favour populist conceptions of national history, prioritized that field of study. There, one could do detailed „thick“ social history of „the people“. In parallel, the study of peasant-workers and all varieties of agrarian labour was facilitated by one of the most schematic dogmas of Eastern European Marxism Leninism, namely the concept of the „alliance of the workers and the peasants“. Among other things, that concept was rooted in the idea that the protracted transition to capitalism in the region meant that peasant-workers had formed an important basis for revolution. Last but not least, the circumstances and position of the Eastern European agrarian population were at the

18 For more on the Hungarian case, see Susan Zimmermann, „The Agrarian Working Class Put Somewhat Center Stage: An Often Marginalized Group of Workers in the Historiography of Labor Written in State-Socialist Hungary“, European Journal of History (under review).

19 Esther Kingston-Mann, „Transforming Peasants in the Twentieth Century: Dilemmas of Russian, Soviet and Post-Soviet Development“, in: Suny, Twentieth Century, p. 412.

20 Examples involving comparative or cross-national dimensions include Emil Niederhauser, A nagybirtok és a parasztság Kelet-Europában a polgári forradalmak után (Debrecen, 1961); T(ibor) Kolossa, Beiträge zur Verteilung und Zusammensetzung des Agrarproletariats in der ÖsterreichischUngarischen Monarchie, vol. 51, Studia Historica, Separatum (Budapest, 1961); Âkos Egyed, Lajos Vajda, and Ion Cicalá, Munkás- és parasztmozgalmak Erdélyben 1905-1907 (Bucharest, 1962); Péter Gunst (ed.), Kelet-Európa agrárfejlödése a századfordulón (1880-1914) (Budapest, 1989). 
core of the debate on the development of Eastern Europe, which will be reviewed further below.

The fact that during Wave One most authors consistently attached the label „feudal remnant“ to some forms of agricultural labour and called others „transitional“ still did not limit their interest in exploring how various forms of labour mingled and affected each other. A monumental 1960s publication dealing with the history of the peasantry in Hungary between 1848 and 1914 pursued an inclusive research agenda in that it included those strata of the agrarian population which were outside all means of production and those who, alongside their smallholdings, fell back on wage labour. Such individuals would be traditional cottars, servants, so-called summás workers, who were seasonal workers often from distant regions who brought their own tools and were recruited for a fixed period of time. Others might be inhabitants of the problem zone where the world of agrarian labour was experiencing „disintegration“. The latter included workers still connected to or based in their villages but working at the margins of or outside that sphere. Examples of such workers are the pick and shovel men, or cubics, and forestry workers, and those who broke out of the village setting by seeking refuge from it in migration within and beyond their country, but especially overseas. As István Szabó, doyen of Hungarian peasant history, summarized it, „The concept of the peasantry in this larger sense is - eminently dissimilar class bonds notwithstanding - defined and bound together by economic, social, lifestyle-related, and cultural indicators“. ${ }^{21}$

Wave Two added new studies on agrarian labour, even though interest in the subject was now more often reduced to something of a sideshow in peasant studies more generally. There are new studies on policies such as collectivization, yet they hardly touch upon the transformation of labour and livelihood that came with collectivization. ${ }^{22}$ Leonard G. Friesen's study, to mention one publication on rural transformation in an earlier period in Southern Ukraine, includes a brief discussion of how, before the mid-nineteenth century, new production strategies and changes to crops resulted in a shortage of labour and functioned as a push towards hired labour; in later decades this created tensions around labour control and between local and migratory labour. ${ }^{23}$

21 The quotation is from Szabó’s 1961 foundational conceptual study, reprinted in István Szabó, Jobbágyok-parasztok. Értekezések a magyar parasztság történetéből (Budapest, 1976); idem, A parasztság Magyarországon a kapitalizmus korában 1848-1914 (Budapest, 1965).

22 An example is the otherwise substantial volume by Constantin Iordachi and Arnd Bauerkämper (eds), The Collectivization of Agriculture in Communist Eastern Europe: Comparison and Entanglements (Budapest and New York, 2014).

23 Leonard Friesen, Rural Revolutions in Southern Ukraine: Peasants, Nobles, and Colonists, 1774-1905 (Cambridge, MA, 2008). 


\section{Women's paid work}

There is abundant evidence that women and girls in modern Eastern Europe have long been substantially involved in gainful employment. In 1853 women - many of them peasant-migrants - owned 107 (11 per cent) of all registered enterprises in Moscow and the Moscow district. ${ }^{24}$ In the second half of the nineteenth century many girls under the age of ten worked between April and September as goose watchers on the Great Hungarian Plain, spending those long months in remote hamlets far away from their parents. $^{25}$

Three themes have been of key importance in making women's paid work visible and revealing its role in the gendered division of labour in Eastern European societies. First is women's role in farming and agriculture; second, the contested process of women's initial entry into the paid labour force in the nineteenth and the early decades of the twentieth centuries; and, third, scholarship has considered women's mass entry into and work within the non-agricultural sectors of the labour market under state socialism. ${ }^{26}$ Historical research into those three large themes has developed unevenly, and there is still little reflection on broader implications beyond Eastern Europe of the findings of that research, and little comparative thinking on the subject.

The history of women's work under the impact of pre-state-socialist industrialization has been studied from a number of perspectives. Working women were to be found in factories in increasing numbers and proportions in many places, yet domestic service, too, proved to be a persistent source of paid work for women. In 1910 in the Hungarian kingdom domestic servants comprised forty per cent of the non-agricultural female workforce, and the figure was the same even in the capital city, a fast growing industrial hub with close to a million inhabitants. Figures were similarly high in partitioned and interwar Poland. Everywhere, the female labour force suffered from enormous women-specific wage discrimination and unequal access to the labour market as compared with men, with particular restrictions on access to learned professions and other skilled work. In addition, working women were discriminated against by social policy legislation largely because their work, for instance as domestic

24 Boris B. Gorshkov, „Serfs on the Move: Peasant Seasonal Migration in Pre-Reform Russia, 1800 -61“, Kritika: Explorations in Russian and Eurasian History, 1, 4 (2000), pp. 627-656, at 649. 25 Lajos Kiss, A szegény asszony élete (Budapest, 1943), pp. 6-31; the book was reprinted several times in Hungary under state socialism.

26 Christine Schindler (ed.), Der Forschungsstand zum Thema „Klasse und Geschlecht“ in Zentral- und Osteuropa (Vienna, 1993), gives a good bibliography on studies of women’s work, including historical studies, in Albania, Bulgaria, CIS/USSR (including many works on non-Russian territories), Poland, Czechoslovakia, and Hungary during Wave One and in the early 1990s. Krassimira Daskalova and Susan Zimmermann, „Women’s and Gender History“, in: Irina Livezeanu and Árpád von Klimó (eds), The Routledge History of East Central Europe since 1700 (London and New York, 2017), pp. 272-315, gives up-to-date information on the history and historiography of women's work in East Central and South-eastern Europe. 
servants, was not considered „real work“, and because they were strongly represented among the informal, casual, and seasonal labour force not covered by those policies. In trade unions and the labour movement they were confronted with strong masculinism and once again marginalized. Steve Smith's careful comparison of women's strikes in St Petersburg before 1917 and Shanghai before 1927 points to possible relationships between the often violent and elemental character of those strikes and the marginal position of women in the organized labour movement. Smith discusses relationships among female workers and between male and female workers, as well as employers' manipulations of those relations. ${ }^{27}$

A substantial portion of the new scholarship on the history of women's paid work under state socialism has focused on the mobilization of women for paid labour and their legal treatment. There has been a good deal of attention focused on women in highly feminized or „unusual“ sectors of the labour market, such as the textile or mining industries, and women's involvement in particular institutions of state-socialist labour, such as Stakhanovism. There has been interest, too, in how their involvement in paid work and later the demise of the state-socialist world of labour has affected women's self-identification and status in society at large. ${ }^{28}$ Working women under state socialism were consistently confronted with discrimination and masculinist attitudes both on the shop floor and elsewhere. In the pursuit of their interests and depending on circumstances, women workers therefore mobilized both the statesocialist women's emancipation discourse and the ideological tropes that challenged

27 Barbara Alpern Engel, Between the Fields and the City: Women, Work, and Family in Russia, 18611914 (Cambridge, 1994); Anna Żarnowska and Andrzej Szwarc (eds), Kobieta i praca. Wiek XIX I XX (Warsaw, 2000); Anna Żarnowska, Workers, Women, and Social Change in Poland, 1870-1939 (Aldershot, 2004); Susan Zimmermann, Divide, Provide and Rule. An Integrative History of Poverty Policy, Social Policy, and Social Reform in Hungary under the Habsburg Monarchy (Budapest and New York, 2011); Zsuzsa Fonó, Az ipari nőmunkások helyzetéről a századfordulón (Budapest, 1974); Zsuzsa Fonó, A magyar munkásnők helyzete és szervezettsége a két világháború között (Budapest, 1978); Steve Smith, „Class and Gender: Women's Strikes in St Petersburg, 1895-1917 and in Shanghai, 1895-1927“, Social History, 19, 2 (1994), pp. 141-168.

28 Examples include: Mary Buckley, Mobilizing Soviet Peasants: Heroines and Heroes of Stalin's Fields (Lanham, MD, 2006); Melanie Ilic, Women Workers in the Soviet Interwar Economy: From „Protection“ to „Equality“ (New York, 1999); Eszter Zsófia Tóth, „Shifting Identities in the Life Histories of WorkingClass Women in Socialist Hungary“, International Labor and Working-Class History, Mo. 68 (2005), pp. 75-92; Chiara Bonfiglioli, „Gender, Labour and Precarity in the South East European Periphery: The Case of Textile Workers in Štip“, Contemporary Southeastern Europe, 1, 2 (2014), pp. 7-23; Malgorzata Fidelis, Women, Communism, and Industrialization in Postwar Poland (Cambridge, 2010); Diane P. Koenker, „Men against Women on the Shop Floor in Early Soviet Russia: Gender and Class in the Socialist Workplace“, American Historical Review, 100, 5 (1995), pp. 1438-1464; Tanja Penter, Kohle für Stalin und Hitler. Arbeiten und Leben im Donbass 1929 bis 1953 (Essen, 2010); Daniela Koleva (ed.), Negotiating Normality. Everyday Lives in Socialist Institutions (New Brunswick, NJ, 2012). 
that discourse. ${ }^{29}$ Research has now begun to address topics related to those groups of women, who faced particular hardship or differential treatment compared with other women in the world of work, such as the Romnja, and to look at how women combined different types of work. ${ }^{30}$ So far, however, far less attention has been given to the matter of the management and control of women's paid work, its specific status and function in the state-socialist world of work, and the consequences for women's work when labour became increasingly involved with the global economy - which in many parts of state-socialist Europe happened well before the demise of state socialism. While it is clear that a large proportion of women workers tended to remain in unskilled or semiskilled occupations, more research is necessary to explore fully and think through the stratification of the state-socialist working class, including its gendered dimension. ${ }^{31}$ Women's agricultural work under state socialism is another subject that has been far too little studied. ${ }^{32}$

\section{Unfree labour}

Research on unfree labour in Eastern Europe has focused on three main themes. They are second serfdom and agrarian labour in later periods, coerced labour under National Socialism, and coerced labour within the Gulag system and other forms of direct labour coercion in state-socialist Europe. Other themes, such as German labour force policies in occupied Poland and Lithuania during World War I, or convict labour in Siberia in tsarist Russia, have been addressed by substantial yet so far rather isolated monographs. ${ }^{33}$

The debate on the second serfdom and its long-term consequences in Eastern Europe, which has continued throughout the period under consideration here, can be considered a most lively intervention in and relevant contribution to global labour history. More recent studies dealing with the subject tend to emphasize intra-regional and even local variety. ${ }^{34}$ Whatever their position in the debate, many relevant authors, including the most „revisionist“ ones, some of whom tend to deny the very existence of

29 Éva Fodor, Working Difference. Women's Working Lives in Hungary and Austria, 1945 - 1995 (Durham and London, 2003), pp. 141-145; Jill Massino, „Constructing the Socialist Worker: Gender, Identity and Work under State Socialism in Braşov, Romania“, Aspasia, 3, 1 (2009), pp. 131-160.

30 For a review see Susan Zimmermann, „Gender Regime and Gender Struggle in Hungarian State Socialism“, Aspasia, 4, 1 (2010), pp. 1-24.

31 Mark Pittaway, From the Vanguard to the Margins. Workers in Hungary, 1939 to the Present (Leiden and Boston, 2014).

32 Beatrice Farnsworth and Lynne Viola (eds), Russian Peasant Women (New York and Oxford, 1992), assembles some classic studies.

33 Christian Westerhoff, Zwangsarbeit im Ersten Weltkrieg (Paderborn, 2012); Elzbieta Kaczynska, Das größte Gefängnis der Welt. Sibirien als Strafkolonie zur Zarenzeit (Frankfurt am Main, 1994).

34 For an excellent recent overview on the debate, with many references to empirical works, see Markus Cerman, Villagers and Lords in Eastern Europe, 1300-1800 (Basingstoke, 2012). 
second serfdom, agree that agrarian labour from the sixteenth to the nineteenth century was characterized by more and more protracted „unfreeness“ in many regions of Eastern as compared with Western Europe. However, once transatlantic slavery and the abolition of slavery as a form of coerced labour associated with Western European powers and developments is brought into the picture, the historical East-West unbalance in terms of the unfreedom or freedom of labour is thoroughly disrupted. ${ }^{35}$

For decades, the conceptual debate consistently situated the history of unfree serf labour in Eastern Europe within a pan-European or even global setting. Authors writing in the liberal tradition maintained that the lack of freedom of labour was one of the root causes of the economic backwardness of Eastern Europe, or that it certainly helped exacerbate it. By contrast, Marxist historians such as Zsigmond Pál Pach have argued that the „'second edition' of serfdom“ in Hungary was generated as a result of the „world market relationships arising since the sixteenth century“, which created a „disadvantageous, economically dependent situation“. The limited development of commodity production and the fact that the transition from feudalism to capitalism was „delayed“ in comparison to Western Europe and „different, occurring under particular circumstances“ were both consequences of that foundational relationship. Pach discusses, too, the various forms and combinations of the employment and bonding of such labour, and the decreasing role of paid labour within that setting in the seventeenth century - basing what he says on empirical material and, of course, stressing that agrarian wage labour at that time was not free labour in the „double sense“ of labour under capitalism. ${ }^{36}$ World-system analysis would later be built on the work of authors such as Pach and the Polish historian Witold Kula.

More recently, research on agrarian unfreedom has become more comparative and tends to think of more and less constrained agrarian labour in different world regions as a continuum. These newer studies have also questioned unfreedom's economically constraining or thoroughly negative effects. ${ }^{37}$ Reference to trans-regional connections in co-producing labour relations, including second serfdom and other forms of agrarian unfreedom that characterized Eastern Europe from the early modern period to the nineteenth century, is visibly in retreat, while recent research on developments within Eastern Europe is methodologically and conceptually sophisticated. Examples include the study by T.K. Dennison and Sheilagh Ogilvie, which, comparing two serf estates in early modern Bohemia and pre-emancipation Russia, argues that serf communities were important in shaping social and labour relations on their estates and forging relationships with overlords and other authorities. The authors

35 Alessandro Stanziani has done much to advance this perspective; a good summary can be found in Alessandro Stanziani, „Russian Serfdom: A Reappraisal“, Ab Imperio, 2 (2014), pp. 71-99, especially $92 \mathrm{f}$.

36 Zsigmond Pál Pach, Die ungarische Agrarentwicklung im 16-17. Jahrhundert. Abbiegung vom westeuropäischen Entwicklungsgang (Budapest, 1964), especially pp. 37 f., 74-80, 92.

37 Stanziani, „Russian Serfdom: A Reappraisal“, argues that both before and after the abolition of serfdom in Russia in 1861 economic growth had been higher than previously assumed. 
suggest that their findings should caution everyone against making generalizations about the positive effects of horizontal social capital on overall economic performance. ${ }^{38}$ Markus Cerman, discussing the new research on varieties of constrained labour in early-modern East Central and Eastern Europe, concluded that ,it is not always possible to distinguish clearly between individual forms of labour constraints and 'free' wage labour in practice". 39

In parallel, and beginning with Peter Kolchin's by now classic 1987 study on American slavery and Russian serfdom, a number of publications have restaged the classic debate, discussing unfreedom in Eastern Europe with reference to the context of colonial slavery and unfree labour in the West. For Kolchin, constrained labour in Russia and slavery in the American South, both labelled „non-capitalist productive systems“", were responses to the growing interest of landlords and plantation owners in commerce and the market opportunities for them when combined with the scarcity of labour in the regions of agricultural expansion. ${ }^{40}$ More recently, Alessandro Stanziani, while confirming the insight that historically market development could and often did rely on coerced labour, has presented a different argument. Constraints on labour in Russia from the seventeenth to the nineteenth century were much more multifaceted and combined more flexibly with wage labour than previously thought. There was more movement away from constraining labour before 1861, and constraints were not abruptly lifted by abolition. Such flexibility, together with „relaxing legal constraints“, explains the similarly revisionist and much more optimistic estimations of economic growth and market development in Russia in the period. Stanziani explicitly denies the relevance of „developing markets in the West“ as a potential „origin of increasing bondage in the East". ${ }^{41}$ While in fact none of the above arguments is related to the question of intra-European or global economic interaction - nor would they be required to be - Stanziani thereby ensures that his argument must be read as focusing on intra-Russian explanations for degrees and development of labour coercion. At the same time, he describes Eastern European unfree labour as an extreme variant of a continuum between East and West and clearly distinguishes the labour system in Russia from colonial slavery.

At present then, thinking globally about unfree agrarian labour in Eastern Europe appears to entail two conceptual moves. The paradigm of Eastern European particu-

38 T.K. Dennison and Sheilagh Ogilvie, „Serfdom and Social Capital in Bohemia and Russia“, Economic History Review, 60, 3 (2007), pp. 513-544.

39 Markus Cerman, „Constrained Labour in Early-Modern Rural East-Central and Eastern Europe: Regional Variation and its Causes“, in: Alessandro Stanziani (ed.), Labour, Coercion, and Economic Growth in Eurasia, 17th-20th Centuries (Leiden, 2013), pp. 189-214, here 214.

40 Peter Kolchin, Unfree Labor. American Slavery and Russian Serfdom (Cambridge, MA, 1987), especially pp. 17-31, 359ff. One recent volume bringing together research into the history of unfree labour in Eastern Europe with developments elsewhere in „Eurasia“ is Stanziani, Labour, Coercion, and Economic Growth in Eurasia.

41 Alessandro Stanziani, Bondage. Labor and Rights in Eurasia from the Sixteenth to the Early Twentieth Centuries (New York, 2014), especially pp. 138f.; idem, „Russian Serfdom: A Reappraisal“. 
larity has been replaced by recognition of the intra-Eastern European and global diversity of labour relations and the shifting local varieties and combinations of freedom and unfreedom. The Eastern European historiography and debate on unfree agricultural labour has made a lasting contribution to this changing landscape of research in regional and global labour history. At the same time, many authors no longer systematically include either the asymmetric economic division of labour in global capitalism or trans-regional market forces as important factors to be investigated when wishing to explain the emergence or prolongation of unfree labour in Eastern Europe - and by implication across the globe. In recent years we have thus witnessed a double shift in research on the history of unfree labour in Eastern Europe. The unfolding of more global and inclusive deep research into the forms and historical persistence of unfree labour has been combined with reduced interest in the relationship between the global and regional development of capitalism on the one hand and the history of unfree labour on the other. Yet the importance of that relationship to the global study of labour is epitomized by the theme addressed in the following section.

\section{On the move}

Important long-term features of the history of labour in Eastern Europe have been the instability, fluidity, and volatility of the work and labour relations of ordinary people, and that has long been recognized. A very important element of this history has been geographical mobility, including for seasonal work and other forms of temporary migration within and across political and national borders, as well as mass longdistance migration and considerable re-migration. Ulf Brunnbauer recently argued that migration has been a key defining characteristic of the overall modern history of Balkan societies, including the repercussions from emigration on the societies of origin. ${ }^{42}$ For both Russia and East Central Europe it is safe to adopt that diagnosis without hesitation. Two recent essays, by Aleksandr V. Gevorkyan and Serguey Ivanov $^{43}$ covering the seventeenth to the nineteenth and the twentieth to the twenty-first centuries respectively, together give an insightful overview of the manifold migration movements so foundational for the Russian Empire.

As compared with other aspects of the history of migration in, from, and to Eastern Europe, there are fewer studies on the impact on the countries of origin of the largescale emigration of labour out of the region. At times, emigration took on dramatic

42 Ulf Brunnbauer, Globalizing Southeastern Europe. Emigrants, America, and the State since the Late Nineteenth Century (Lanham etc., 2016).

43 Aleksandr V. Gevorkyan, „Russia, Migration 17th-19th Century“, in: Immanuel Ness (ed.), The Encyclopedia of Global Human Migration (Chichester, 2013), vol. 5, pp. 2665-2671; Serguey Ivanov, „Russian Internal Migration, Early 20th Century to Present“, in: ibid., pp. 2671-277. 
proportions, and useful studies of its effect on the world of work within the region are especially lacking. ${ }^{44}$

The large-scale mobility of the agrarian masses and other ordinary people took different forms in different parts of Eastern Europe. In the Habsburg Empire there was more pronounced internal migration within Austria as compared with Hungary (including Croatia). The populations on the eastern and southern peripheries of the empire were included in other migration circuits that tended to cross borders. Between the 1870s and the 1920s up to four million people emigrated from Austria and Hungary, sometimes accompanied by sizeable return migration, with women making up consistently more than forty per cent of emigrants. The territories of partitioned Poland saw a similarly dramatic migration wave following, as Ewa Morawska has argued, the „Western penetration“ and the end of serfdom in the nineteenth century. The dramatic decrease in the size of many peasant holdings, the destruction of traditional rural handicrafts as a complementary source of income, and the development of transport all contributed to the process. Taking border-crossing and internal migration together, between 1860 and 1914 approximately ten million individuals were on the move a third of the population. In the years before World War I annually more than half a million workers from Austrian and Russian Poland left for Germany as seasonal migrants. ${ }^{45}$ The large-scale migration processes in East Central Europe brought many workers from peasant backgrounds into the quickly growing cities within the regions, and migration history has explored, among other things, the relationship between that phenomenon and local working-class cultures and labour movements in these cities. ${ }^{46}$

The Balkans saw significantly less emigration than did Austria-Hungary, at least if we exclude Croatia and Slovenia, both of which belonged to the Habsburg Monarchy. However, as the nineteenth century ended, overseas migration gained ground dramatically in the Balkans, too, certainly when compared to the more traditional migration between the different Balkan polities and to other parts of the Ottoman Empire. Persistent large wage differentials between the region and Western destinations of emigration, falling travel costs, and locally closed borders all made important contributions to a considerable exodus from the Balkans. The tradition of itinerant labour

\footnotetext{
44 See, however, Dirk Hoerder, Horst Rössler, and Inge Blank (eds), Roots of the Transplanted (New York, 1994); Brunnbauer, Globalizing Southeastern Europe.

45 Emigration from Galicia of course is included in the numbers for both Austria-Hungary and partitioned Poland. Annemarie Steidl, „On Many Roads: Internal, European, and Transatlantic Migration in the Habsburg Monarchy, 1850 -1914“ (Habilitation, University of Vienna, 2014); idem, „Ein ewiges Hin und Her. Kontinentale, transatlantische und lokale Migrationsrouten in der Spätphase der Habsburgermonarchie“, Österreichische Zeitschrift für Geschichtswissenschaft, 19, 1 (2008), pp. 15-42; Ewa Morawska, „Labor Migrations of Poles in the Atlantic World Economy, 1880-1914“, in: Dirk Hoerder and Leslie Page Moch (eds), European Migrants: Global and Local Perspectives (Boston, 1996), pp. 170 208.

46 Anna Żarnowska, „Rural Immigrants and Their Adaptation to the Working-Class Community in Warsaw“, in: Hoerder et al., Roots of the Transplanted, vol. 2, pp. 289-304; Péter Sipos, „Migration, Labor Movement and Workers’ Culture in Budapest, 1867-1914“, in: ibid., pp. 155-171.
} 
included seasonal migration from mountain villages or semi-sedentary lifestyles connected to animal husbandry - rather reminiscent of our goose-watching girls on the Great Hungarian Plain - and it had long been „a mainstay of economic life in the Balkans“. In due course the tradition of itinerant labour was to become an important generator of long-distance migration. ${ }^{47}$

For a long-term perspective on Russia we must highlight a number of large-scale types of mobility. All the relevant types of mobility were connected with or even based on corresponding immobility regimes, in other words they depended on foundational legal and administrative restrictions and controls on mobility. Organized politics of the settlement and resettlement of agrarian labour, aimed at sustaining and stabilizing imperial expansion, took on unprecedented dimensions from the late eighteenth century onwards. Between the seventeenth and nineteenth centuries ,the scale [of human migration] was immense and the process slow“, including large-scale colonization projects in Siberia, the Far East, and the Caucasus, so that ,in the end, the Russian Empire stood as the rightful heir to that era“. ${ }^{48}$ Both before and after the end of serfdom in 1861 these settlement policies combined with more pronounced and individualized mobility from village to village, estate, town, and city. Millions of peasants, male and female, temporarily and often in seasonal rhythm, left their villages to work, some of them far away, as labourers, craftsmen, traders, and entrepreneurs. In the mid-nineteenth century, in the central provinces, over a five-year period roughly a quarter of adult male peasants received permission to migrate temporarily, although the actual proportion of peasants on the move in any given year was considerably higher. One result was the notorious irregularity and instability of the urban workforce. ${ }^{49}$ Steve Smith argues that the agency and changing identity of masses of peasants migrating throughout the decades to St Petersburg and Shanghai respectively played an important role in the revolutionary processes that later went on in both Russia and China..$^{50}$ From the second half of the nineteenth century, border-crossing migration into the Russian Empire, notably from the north-western Iranian province of Azerbaijan, became a mass phenomenon. An estimated 200,000 to 300,000 people, a considerable proportion of them women, crossed Russia's Asian frontiers every year, often for seasonal agricultural work, craftsmen's work, and trade. Considerable numbers of Persians toiled in the Baku oil industry, and as foreigners the migrants

47 Brunnbauer, Globalizing Southeastern Europe, especially chs 1 and 2; Holm Sundhaussen, „Southeastern Europe“, in: Klaus J. Bade et al. (eds), The Encyclopedia of Migration and Minorities in Europe: From the 17th Century to the Present (Cambridge, 2011), pp. 163-181.

48 Gevorkyan, „Russia, Migration 17th-19th Century“, p. 2670; Richard Hellie, „Russia and Belarus“, in: Bade et al., Encyclopedia of Migration and Minorities in Europe, pp. 181-192.

49 Gorshkov, „Serfs on the Move“, also gives the more extensive earlier literature on the postemancipation period.

50 S.A. Smith, Revolution and the People in Russia and China: A Comparative History (Cambridge, 2008). 
suffered particular discrimination. ${ }^{51}$ Ramin Taghian's careful study illuminates how the Central Asian or Russian experience of so many workers reverberated in the history of the Iranian socialist movement and the Constitutional Revolution in Iran from $1905^{52}$

As a result of large-scale state-led industrialization and collectivization of the agrarian world, migration remained an important feature of the history of labour within the Soviet political sphere. In addition, the borderlands of the Soviet empire, including the republics of Moldova, Armenia, and Georgia, to varying degrees remained net immigration zones until as late as the 1960s or 1970s. In parallel, new types of mobility control and restriction were set in motion, such as the introduction of compulsory internal passports in $1932 .{ }^{53}$ The control of internal mobility was an important feature of state-socialist policies all over Eastern Europe after 1945.

The study of migration and Eastern Europe can make important contributions to global labour history. First of all it helps to decentralize the global history of labour and labour migration by focusing on migration from, within, and, for the earlier periods in particular, to the region as a permanent and pronounced feature of the history of Eastern Europe. It also sheds light on the connection between modern economic development within and trans-regional divisions of labour beyond Eastern Europe on the one hand, and the mobilization of labour in the region on the other. Within the region, industrialization processes and efforts were dynamic, although before the advent of state socialism they were often insular too. However, these processes and efforts were one of the root causes that set Eastern European labour in motion. For example, Peter Kriedte has recently argued that in the first half of the nineteenth century power elites in Congress Poland, making use of a border protected by a tariff barrier, systematically generated eastward immigration of skilled workers in order to promote the beginnings of a textile industry. ${ }^{54}$ The exodus of millions of people from the agrarian world could not have happened without a great agrarian transformation, which often came with pronounced wage pressure on agrarian labour in Eastern Europe. In the nineteenth and early twentieth centuries the changes were in large

51 Hassan Hakimian, „Wage Labor and Migration: Persian Workers in Southern Russia, 1880 - 1914“, International Journal of Middle East Studies, 17, 4 (1985), pp. 443- 462.

52 Ramin Taghian, Grenzgänger des Sozialismus. Die transnationale Dimension der frühen sozialistischen Bewegung im Iran (1905-1911) (Vienna, 2014). Habib Ladjevardi, Labor Unions and Autocracy in Iran (New York, 1985), also touches on these migrations and interactions, and pursues a transnational perspective in relation to later decades too.

53 Lewis H. Siegelbaum and Leslie Page Moch (eds), Broad is my Native Land. Repertoires and Regimes of Migration in Russia's Twentieth Century (Cambridge, 2014); Siegelbaum, „Workers and Industrialization“, pp. 446 f.; Attila Melegh, Diverging Historical Development of Migration in Southeastern Europe since 1950 (Budapest, 2013), especially pp. 26 f.; Dirk Hoerder, Migrations and Belongings 1870-1945 (Cambridge, MA, 2012), especially pp. 35-39.

54 Peter Kriedte, „Migration, Gewerbepolitik und Industrialisierung. Die letzte Phase der West-OstWanderung und die Anfänge des mittelpolnischen Textilindustriereviers (1815-1850)“, Zeitschrift für Ostmitteleuropa-Forschung, 61, 2 (2012), pp. 163-218. 
measure an offshoot of the integration of Eastern European agriculture in trans-European and global markets, and of liberal political reform. The large-scale emigration that followed was directed not only towards the West; it included, for example, the relocation of more than 100,000 Ukrainians to Siberia alone in the second half of the nineteenth century. The great movement that followed the abolition of serfdom in 1861 and gained even more momentum as a result of the Stolypinian agrarian reform after the turn of the century was encouraged and orchestrated by the tsarist government, which promised access to land to this impoverished agricultural population in the faraway region. ${ }^{55} \mathrm{~A}$ not insignificant factor that contributed to setting Eastern European labour on the move was that the trans-European and global integration of agriculture caused agrarian labour in the region to become dependent on international and faraway business cycles. The strong emigration movement itself also had important, though insufficiently studied, effects on the places of origin, in terms of both agrarian labour relations and wages and the availability of remittances - or lack of them. ${ }^{56}$

Second, besides economics politics have always been at the core of the history of migration in the region. State-led settlement and colonization policies were emphasized in particular and over long periods under the Russian Empire, while in the statesocialist period, even though there were policies of bringing industrial employment to people living in remote places, state-led economic development endeavours were built everywhere on the mobilization of labour across space. After 1945, when the rest of Europe saw another large labour-centric migration wave, the state-socialist regimes everywhere (with the exception of Yugoslavia) strictly controlled and regulated Eastern European labour emigration, especially to the West. Even in net-emigration countries such as Hungary, Romania, Bulgaria, and Albania the net emigration ratios remained low compared with those for some other countries in economically similar positions. In those rare instances, when control was relaxed or restrictions were selectively lifted the resulting migration waves, such as that after the 1956 uprising in Hungary or the Jewish emigration from Poland and the Soviet Union between the end of the 1960s and the 1980s, were driven by both political motives and the search for a better life in the West. ${ }^{57}$ For the most part, under state socialism labour migration was contained within the Eastern bloc and managed through closely controlled migration accords within

55 „Ukraine“, in: Bade et al., Encyclopedia of Migration and Minorities in Europe, p. 198; Vladimir Shaidurov, „Ukrainians in Western Siberia in the Second Half of the 19th - Early 20th Century: Specific Features Characterizing Their Resettlement and Economic Adaptation“, Acta Histriae, 24, 2 (2016), pp. 313-336, especially 319-325.

56 Brunnbauer, Globalizing Southeastern Europe, especially pp. 118-126.

57 Melegh, Diverging Historical Development of Migration, p. 16; Dariusz Stola, Kraj bez wyjścia? Migracje z Polski 1949-1989 (Warsaw, 2010); Ruth Moshkovitz, „'Ich bin nur froh, dass die Sowjetunion uns nicht zurückgenommen hat.' Bucharisch-jüdische (Re-)Migration nach Wien im Kontext transnationaler Vergeschlechtlichung und Rassifizierung“ (Diplomarbeit, University of Vienna, 2016). 
Eastern Europe, and from the 1960s with countries in the communist Global South. ${ }^{58}$ The organized intake of labour from the Global South, for instance through the CzechVietnamese labour exchange programme inaugurated in $1967,{ }^{59}$ indicates both the state-socialist endeavour of building an alternative world system, and the insatiable hunger for labour that characterized the heyday of state-led state-socialist economic development. It is probable that the need for new cheap labour played a role in generating these programmes, as integration into the world economy increased.

This picture of labour migration under state socialism raises a number of questions especially about the relationship between the politics of labour migration on the one hand and trans-European and global economic disparities and polarization on the other. Was political control of migration in state-socialist Europe more likely to succeed when economic catching-up was successfully under way, or did it work because of the strong „,visible hand“ of the socialist state? Did keeping the labour force at home contribute to the economic catch-up? Comparatively speaking, what were the consequences for the development of the home countries and societies of a mass exodus of the labour force in cases such as those of Greece, Spain, and Yugoslavia? These questions might be productively addressed by future research. In more general terms, the study of labour on the move could benefit from close attention to the relationship between the various waves of ,untying“ and mobilizing it and the changing forms of controlling it. ${ }^{60}$ Nor, of course, should we forget discrimination against migrant labour in terms of wages, rights, and welfare in the hubs of modern economic development, and the fates and fortunes of economic and social development in Eastern Europe as key factors shaping the dynamics of labour migration and the experience of workers in and from Eastern Europe.

\section{Social reproduction and subsistence labour}

In most of the historiography reviewed for this essay both the labour of social reproduction and non-commodified subsistence labour, while repeatedly mentioned and often regarded as given, are either not considered to be work or not mapped and discussed in conceptual terms within a framework of labour history. Yet it can be argued that a focus on unpaid labour for social reproduction and on subsistence la-

58 Dorota Praszłowicz, „Poland“, in: Bade et al., The Encyclopedia of Migration and Minorities in Europe, p. 148; Alena K. Alamgir, „Recalcitrant Women: Internationalism and the Redefinition of Welfare Limits in the Czechoslovak-Vietnamese Labor Exchange Program“, Slavic Review, 73, 1 (2014), pp. $133-155$.

59 Alena Alamgir, „Race is Elsewhere: State-Socialist Ideology and the Racialisation of Vietnamese Workers in Czechoslovakia“, Race and Class, 54, 4 (2013), pp. 67-85.

60 Andrea Komlosy’s „State, Regions, and Borders: Single Market Formation and Labor Migration in the Habsburg Monarchy, 1750 -1918“, Review, 27, 2 (2004), pp. 135-177, discusses some of these connections, with a focus on Cisleithanian Austria. 
bour is not only a basic requirement for developing more inclusive perspectives on the history of all labour. In addition, it contains the potential to develop a deeper understanding of the history of commodified labour (regardless of its status and ties with social policy measures). Many characteristics of and developments in the world of paid labour can be more adequately understood if explored from the perspective of their connection with unpaid labour. The commodification of formerly unpaid labour, as well as the lack of it, has in fact had important ramifications for the history of paid labour.

A number of studies on Russian and early Soviet industrialization, on home industries, and on women's work under state socialism have already laid some groundwork for such a broadened view of the history of labour. Much has been written about the Russian peasant-proletariat. The social reproduction of Russian factory workers, which remained connected to the village and agrarian labour, was in part ensured through their own and their families' subsistence labour. ${ }^{61}$ Gijs Kessler has argued that from a long-term global and comparative perspective the complementarity of subsistence and wage labour, so visible as a defining feature of Russian labour history, no longer appears to be an Eastern European particularity. By contrast, the Soviet period stood out globally for a particularly pronounced decrease in the proportion of individuals and households who combined gainful employment and subsistence labour. ${ }^{62}$ At least in its initial decades the enforced state-socialist industrialization project that formed the backdrop of that development resulted in a dramatic squeeze on labour for social reproduction. That was especially true because women were drawn into the labour force in unprecedented numbers and proportions. While men were unwilling to participate more equally in unpaid „women’s work“ for social reproduction, the state-socialist regimes did not invest sufficiently in the transformation of unpaid work for social reproduction into paid labour, for instance in social services, canteens, and the like. ${ }^{63}$ The tense connection between the labours of social reproduction and the increasing involvement of the population in paid labour stood at the core of some of the hardship of early state socialism. This hardship was important in generating both anti-communist attitudes and action, and the policies of repression deployed so thoroughly in the period. From yet another perspective it can be argued that however much it suffered from the squeeze discussed above, unpaid domestic labour enabled „cheap“ industrialization in the Soviet Union and other state-socialist

61 Victoria E. Bonnell (ed.), The Russian Worker. Life and Labor under the Tsarist Regime (Berkeley, 1983); Gijs Kessler, „The Rural-Urban Nexus in Russian Labour History, 1860s-1930s: Suggestions for a Global, Comparative Perspective“, in: Marcel van der Linden and Prabhu P. Mohapatra (eds), Labour Matters: Towards Global Histories. Studies in Honour of Sabyasachi Bhattacharya (New Delhi, 2009), pp. 207-225.

62 Gijs Kessler, „Wage Labour and the Household Economy: A Russian Perspective, 1600 - 2000“, in: Marcel van der Linden and Leo Lucassen (eds), Working on Labor. Essays in Honor of Jan Lucassen (Leiden and Boston, 2012), pp. 353-369.

63 Zimmermann, „Gender Regime and Gender Struggle“. 
countries. In both urban and rural contexts work on quasi-private plots of land generated resources indispensable for survival, especially in very hard times. The reintroduction in the Soviet Union of such plots in the middle of the brutal drive to agrarian dispossession and collectivization of the 1930s has been described as an „extraordinary and rare concession from the Stalinist state“ brought about by rural resistance that was led by women. As an ubiquitous feature of life under state socialism, the private plot helped to keep wages low so that more resources could be transferred to the accumulation fund used to finance catch-up industrialization. ${ }^{64}$

What were the repercussions of the connection between agrarian subsistence labour and industrial wage work embodied by the peasant-worker on both industrial development and subsistence labour in tsarist Russia? What was the overall role of the quasi-private agricultural plot in the state-socialist development project? My own admittedly limited review of the vast literature on the Russian peasant-worker and agrarian labour under state socialism was in part directed by those large questions. Beyond the work of Teodor Shanin on late imperial Russia and the very beginnings of the socialist period ${ }^{65}$ and the debate around it - now long in abeyance - I have encountered no systematic interest in translating what is an enormous subject into manageable research projects.

At the same time, many of the studies I have reviewed for this essay on work in the industrialized and industrializing societies of Eastern Europe can be read in new ways if we place at centre stage the role played by the unpaid labours of social reproduction and subsistence in shaping the world of gainful labour. A few glimpses must suffice here. When women workers went on strike in St Petersburg before 1917 the few genderspecific demands they raised were to do with working hours and matters of maternity. ${ }^{66}$ That points up the fact that the dissimilar involvement of women and men in social reproduction had discernible repercussions on how men and women related differently to the world of paid work. A study of early state socialism in Poland reveals that a number of woman-specific problems in the world of paid labour can be explained with reference to the association of women's paid labour with their unpaid work for the family ${ }^{67}$ In some parts of the Habsburg Monarchy cottage industries in combination with subsistence agriculture were important for survival, while under the impact of

64 Gijs Kessler, „A Population under Pressure: Household Responses to Demographic and Economic Shock in the Interwar Soviet Union“, in: Filtzer et al., A Dream Deferred, pp. 315-342, especially 342, and the other contributions in Section III of that volume'; Kingston-Mann, „Transforming Peasants in the Twentieth Century“; Ildikó Asztalos Morell, Emancipations Dead-End Roads? Studies in the Formation and Development of the Hungarian Model for Agriculture and Gender, 1956-1989 (Uppsala, 1999); Susan Bridger, „Soviet Rural Women: Employment and Family Life“, in: Farnsworth and Viola, Russian Peasant Women, pp. 271-293.

65 Teodor Shanin, The Awkward Class. Political Sociology of Peasantry in a Developing Society, Russia 1910-1925 (Oxford, 1972).

66 Smith, „Class and Gender“.

67 Natalia Jarska, „Gender and Labour in Post-War Communist Poland: Female Unemployment 19451970“, Acta Poloniae Historica, 110 (2014), pp. 49-85. 
economic liberalization and industrialization that type of work was extremely exploited and its vulnerability, especially when detached from agricultural production, became highly visible. ${ }^{68}$

The examples touched upon in this section suggest that the labour of social reproduction needs to be taken properly into consideration when we try to explain the agency of workers and their families on the one hand and the business and development strategies of employers and states on the other. In the later decades of state socialism governments and employers did more than was done in many other parts of the world to „socialize“ social reproduction. We might well advance our conceptual understanding of patterns of modern economic development and potential alternatives to capitalism by advancing the comparative study of such policies, including their repercussions for the world of labour and society at large.

\section{Concepts, connections, directions}

Many of the phenomena and research examples reviewed in this essay could have been discussed in multiple sections, and the agricultural summás workers in Hungary under the Habsburg Monarchy epitomize them. Women formed part of the labour „gangs“ in which the summás workers were organized but could never be leaders of them. Each individual summás worker was involved in different types of labour and labour relations, did wage work, and owned some of the means of production. These workers were bound to fulfil long-term labour contracts and migrated regularly, some of them to distant places to engage in gainful employment. Many summás workers were of ethnic backgrounds different from local workers, or spoke a different language. Every summás worker was integrated into overlapping cycles of social reproduction, namely at the faraway estate that, during the work season, fed him or her and the „gang“ to which she or he belonged, and in the village back home. However, the explanation for the persistence and change over time of summás work is less obvious. It is difficult to see clearly whether and how pan-European and global connections were involved in and shaped the history of summás work. The place of that sort of work in global labour history deserves further research, and dominant concepts and debates in the new global history give barely any direct guidance. As Wave Two of Eastern European labour historiography gains momentum, questions such as these thus offer promising research avenues.

Among the things the new research can build upon is empirical knowledge produced during Wave One, the period between the 1960s and the demise of state socialism. Even in a less than generous reading, that was a time when a vast stock of more

68 Andrea Komlosy, „Austria and Czechoslovakia: The Habsburg Monarchy and its Successor States“, in: Lex Heerma van Voss, Els Hiemstra-Kuperus, and Elise van Nederveen Meerkerk (eds), The Ashgate Companion to the History of Textile Workers, 1650-2000 (Farnham, 2010), pp. 43-75; Lackó, Ipari munkásságunk összetételének alakulása. 
complex historiographies of labour was built up in Eastern Europe. This insight is not meant to imply that today's researchers should be more excited or affirmative about the scholarship produced during Wave One. Rather, I see my approach as an invitation to all of us to interrogate some of the new global labour history more critically, especially, I would argue, for its scant interest in the role that both unequal global economic integration and social reproduction have played in the history of labour in all regions of the world.

From a historiographical point of view it would be worthwhile, then, to think comparatively about the histories of labour already written and still to be written in the West, the Global South, and Eastern Europe. Rather than aiming for comparative value judgement such an endeavour could contribute to our understanding of the impact of the global constellation at a given time in labour history writing. Undoubtedly some of the new transnational and global labour history has lacked critical reflection on its own relationship to the globalization we are seeing today. By contrast, such a layer of added reflection, whenever pursued, has certainly generated more insight and has served to caution us all against complacency. For example, in the new Eastern European historiography of labour, studies on workers' agency under state socialism have emerged in critical response to the totalitarian paradigm so prevalent in the post1989 European historiography in both the East and West. These studies ${ }^{69}$ have begun to generate important new insights and will potentially generate a rethink of workers' agency and labour movements in capitalist contexts too. Developing research on this great theme might therefore help give the global labour history of our own days a more critical edge.

69 Examples include Chris Ward, Russia's Cotton Workers and the New Economic Policy. Shop-Floor Culture and State Policy 1921-1929 (Cambridge, 1990); Bartha, Alienating Labour; Pittaway, From the Vanguard to the Margins; Alena K. Alamgir, ,'Inappropriate Behavior': Labor Control and the Polish, Cuban and Vietnamese Workers in Czechoslovakia“, in: Marsha Siefert (ed.), Labor in State Socialist Europe after 1945: Contributions to Global Labor History (forthcoming); Peter Heumos, „Strikes in Czechoslovakia from 1945 to 1968: Cross-System Aspects and the Debate over the Causes of the Collapse of State Socialism“, in: Siefert, Labor in State Socialist Europe after 1945. 


\section{Suggested reading}

Bartha, Eszter. Alienating Labour: Workers on the Road from Socialism to Capitalism in East Germany and Hungary (New York and Oxford: Berghahn, 2013).

Bonnell, Victoria E. (ed.). The Russian Worker. Life and Labor under the Tsarist Regime (Berkeley, CA: University of California Press, 1983).

Buckley, Mary. Mobilizing Soviet Peasants: Heroines and Heroes of Stalin's Fields (Lanham, MD: Rowman \& Littlefield, 2006).

Cerman, Markus. Villagers and Lords in Eastern Europe, 1300-1800 (Basingstoke: Palgrave Macmillan, 2012).

Engel, Barbara Alpern. Between the Fields and the City. Women, Work, and Family in Russia, 1861-1914 (Cambridge: Cambridge University Press, 1994).

Farnsworth, Beatrice and Lynne Viola (eds). Russian Peasant Women (New York and Oxford: Oxford University Press, 1992).

Fidelis, Malgorzata. Women, Communism, and Industrialization in Postwar Poland (Cambridge: Cambridge University Press, 2010).

Filtzer, Donald A. Soviet Workers and Stalinist Industrialization. The Formation of Modern Soviet Production Relations, 1928-1941 (London: Pluto Press, 1986).

Filtzer, Donald A. Soviet Workers and Late Stalinism. Labour and Restoration of the Stalinist System after World War II (Cambridge: Cambridge University Press, 2002).

Filtzer, Donald A. Soviet Workers and De-Stalinization, The Consolidation of the Modern System of Soviet Production Relations, 1953-1964 (Cambridge: Cambridge University Press, 1992).

Filtzer, Donald A. Soviet Workers and the Collapse of Perestroika. The Soviet Labour Process and Gorbachev's Reform, 1985-1991 (Cambridge: Cambridge University Press, 1994).

Goodwin, Lawrence. Breaking the Barrier. The Rise of Solidarity in Poland (New York: Oxford University Press, 1991).

Haraszti, Miklós. Worker in a Workers' State. Trans. Michael Wright (New York: Universe Books, 1978).

Ilic, Melanie. Women Workers in the Soviet Interwar Economy: From „Protection“ to „Equality“ (New York: Palgrave, 1999).

Kolchin, Peter. Unfree Labor. American Slavery and Russian Serfdom (Cambridge, MA: Harvard University Press, 1987).

Lomax, Bill (ed.). Hungarian Workers' Councils in 1956 (New York: Columbia University Press, 1990).

Murphy, Kevin. Revolution and Counterrevolution. Class Struggle in a Moscow Metal Factory (New York and Oxford: Berghahn, 2005).

Petrungaro, Stefano. „The Fluid Boundaries of 'Work'. Some Considerations Regarding Concepts, Approaches, and South-Eastern Europe“, Südost-Forschungen, 72 (2013), pp. 271-286.

Pittaway, Mark. From the Vanguard to the Margins. Workers in Hungary, 1939 to the Present (Leiden and Boston: Brill, 2014).

Rabinovitch, Alexander. The Bolsheviks Come to Power. The Revolution of 1917 in Petrograd (Chicago: Haymarket Books, 2004).

Rutar, Sabine. „Towards a Southeast European History of Labour: Examples from Yugoslavia“, in: idem (ed.), Beyond the Balkans: Towards an Inclusive History of Southeastern Europe (Münster: LIT, 2013), pp. 325-356.

Shanin, Teodor. The Awkward Class. Political Sociology of Peasantry in a Developing Society, Russia 1910-1925 (Oxford: Clarendon Press, 1972).

Smith, S.A. Revolution and the People in Russia and China: A Comparative History (Cambridge: Cambridge University Press, 2008). 
Stanziani, Alessandro (ed.). Labour, Coercion, and Economic Growth in Eurasia, 17th-20th Centuries (Leiden and Boston: Brill, 2013).

Ward, Chris. Russia's Cotton Workers and the New Economic Policy. Shop-Floor Culture and State Policy 1921-1929 (Cambridge: Cambridge University Press, 1990).

Żarnowska, Anna. Workers, Women, and Social Change in Poland, 1870-1939 (Aldershot: Ashgate, 2004).

Zelnik, Reginald E. Labor and Society in Tsarist Russia. The Factory Workers of St. Petersburg 1855-1870 (Stanford, CA: Stanford University Press, 1971).

Zimmermann, Susan. Divide, Provide and Rule: An Integrative History of Poverty Policy, Social Policy, and Social Reform in Hungary under the Habsburg Monarchy (Budapest and New York: Central European University Press, 2011). 


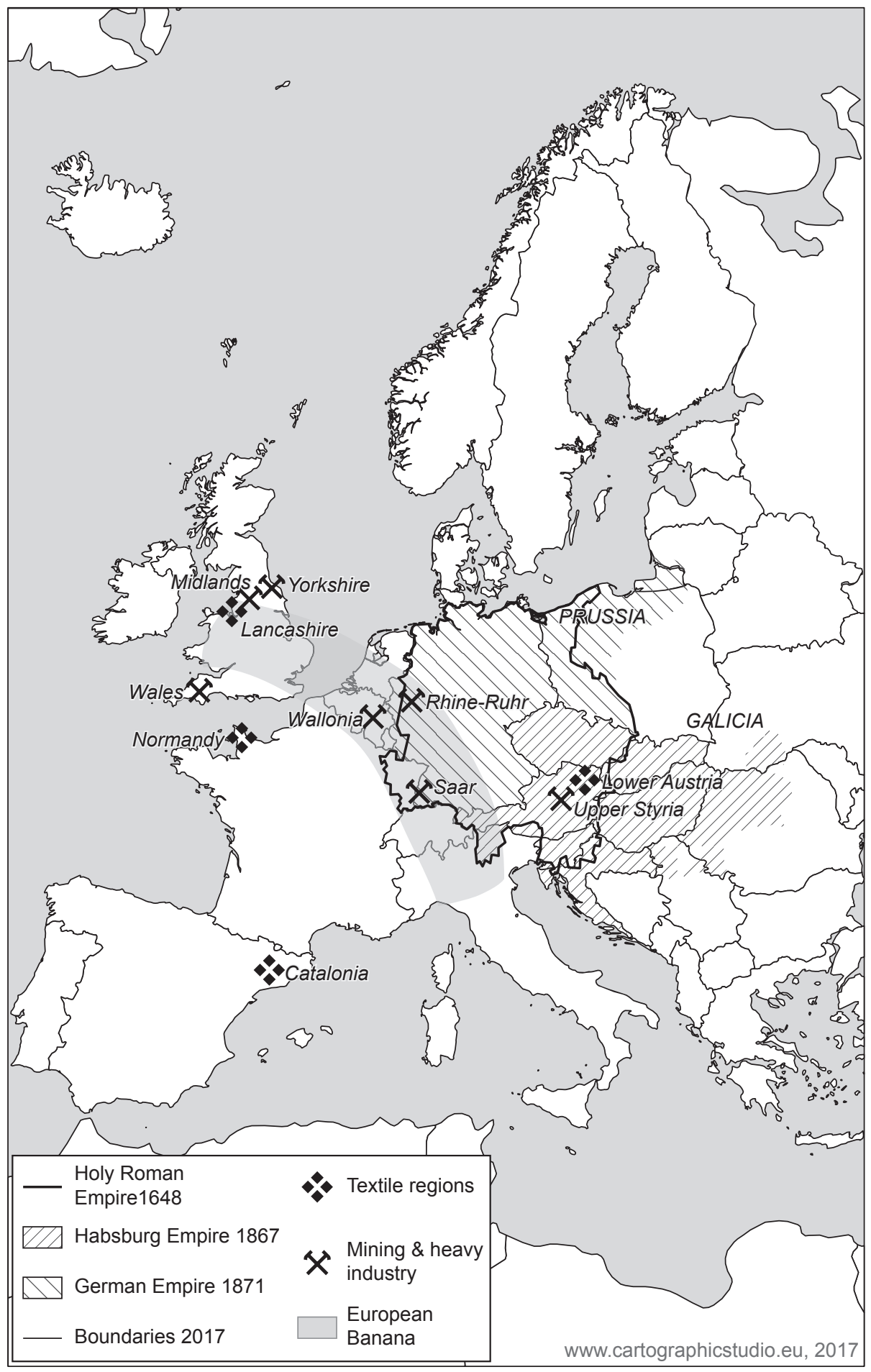

